\title{
PELATIHAN PEMBUATAN ALAT PERAGA MATEMATIKA BERBASIS LINGKUNGAN UNTUK MENINGKATKAN KOMPETENSI GURU SD DALAM PELAKSANAAN KURIKULUM 2013 DI KOTA BENGKULU
}

\section{TRAINING IN CREATING OF ENVIRONTMENTAL MATHS PROPS TO IMPROVE PRIMARY SCHOOL TEACHER COMPETENCE IN EXECUTING 2013 CURRICULUM IN BENGKULU CITY}

\author{
Oleh: \\ Effie Efrida Muchlis, Dewi Rahimah, Syafdi Maizora \\ Staf Pengajar FKIP Universitas Bengkulu
}

\begin{abstract}
Learners are directly related to what the teacher in learning activities and become direct experience of learners. Learning gives real meaning to the learner. By providing props based on mathematical learning environment will give meaning to the other disciplines. By learning math using environment-based learning tools teachers will associate with other subjects. The use of instructional media in teaching and learning is still lacking although the schools have had excellent facilities. This is caused by lack of knowledge and skills of elementary school teachers in the city of Bengkulu in using objects that are available around the environment to be a source of learning, especially math used as props. One of the utilization of objects that exist around the environment in mathematics is a manufacture of environment-based learning tools. The method used is a demonstration, assignments, discussions and question and answer. Through this service activities gained six props is a digital clock, the positive and negative card, card number, card mirroring, square blocks and funnel Commission. The implications of this activity is that it can terbentukya props based math environment more creative, to other subject matter. The conclusion of this study is to improve the ability of teachers to use and utilize existing objects around the environment to be used as props in learning.
\end{abstract}

Keywords: Training, Maths Props, Primary School Teacher

\section{PENDAHULUAN}

Integrasi konten IPA dan IPS DALAM Kurikulum 2013 saat ini untuk Sekolah Dasar adalah berdasarkan makna mata pelajaran sebagai organisasi konten dan bukan sebagai sumber dari konten. Konten IPA dan IPS diintegrasikan ke dalam mata pelajaran PPKn, Bahasa Indonesia dan Matematika. Pembelajaran di SD pada pelaksanaan kurikulum 2013 berdasarkan pada tema. Menurut Kemendiknas tema memberikan makna kepada konsep dasar tersebut sehingga peserta didik tidak mempelajari konsep dasar tanpa terkait dengan 
kehidupan nyata. Dengan demikian, pembelajaran memberikan makna nyata kepada peserta didik. Dengan menyediakan alat peraga yang berbasis lingkungan pada pembelajaran matematika akan memberikan makna kepada bidang ilmu lain. Dengan belajar matematika yang menggunakan alat peraga berbasis lingkungan guru akan mengaitkan dengan pelajaran lain misalnya IPA bahwa kita dapat mendaur ulang kembali benda-benda yang ada disekitar kita, yang tadinya akan menjadi sampah dapat kita gunakan menjadi benda yang lebih bermanfaat.

Alat peraga berbasis lingkungan ini dapat dibuat dengan benda misalnya pipet, kertas kardus, kertas karton, kaleng dan kotak-kotak makanan, korek api dan masih banyak benda lainnya. Melalui alat peraga berbasis lingkungan ini kita dapat menyajikan materi matematika dalam format dan desain yang menarik, menampilkan benda-benda konkrit dalam kehidupan sehari-hari yang dibutuhkan untuk memahami konsep matematika. Melalui alat peraga berbasis lingkungan ini, banyak aktivitas yang dapat dilakukan oleh siswa dan menyesuaikan dengan tingkat kemampuan individu.

Menggunakan alat peraga guru dapat memotivasi siswa untuk fokus kepada materi pelajaran. Selain itu alat pembelajaran merupakan suatu bentuk perangkat pembelajaran, maksudnya alat peraga dapat digunakan untuk mempermudah penjelasan materi yang abstrak, dengan menggunakan alat peraga siswa dapat melihat, meraba dan meggunakan benda tersebut sehingga materi yang diajarkan akan mudah dipahami siswa.

Menurut Sanaki (dalam Asyar) alat peraga dibedakan menjadi 3 kelompok:

a) Alat peraga langsung, yaitu objek sebenarnya yang dibawa langsung kekelas atau dikunjungi ke lokasi dan digunakan menjelaskan materi dengan memperagakan/ menunjukkan kepada peserta didik.

b) Alat peraga tak langsung yaitu alat peraga tiruan (model, miniatur, foto, dll) yang digunakan untuk memperagakan materi ajar dikelas.

c) Peragaan, merupakan kegiatan atau perbuatan yang dilakukan oleh pengajar dikelas untuk mendemonstrasikan suatu materi ajar yang sifatnya psikomotorik.

Pada pelatihan ini alat peraga yang dibuat adalah alat peraga langsung, yaitu alat peraga langsung, dengan menggunakan benda-benda yang ada disekitar lingkungan dan dimanfaatkan untuk menjelaskan materi matematika.

Ada beberapa prasyarat alat peraga menurut Rusefendi dalam Sundayana (2013) yaitu:

1. Tahan lama

2. Bentuk dan warnanya menarik

3. Sederhana dan mudah dikelola

4. Ukurannya sesuai

5. Dapat menyajikan konsep matematika baik dalam real, gambar atau diagram.

6. Sesuai dengan konsep matematika

7. Dapat memperjelas konsep matematika dan bukan sebaliknya.

8. Peragaan itu supaya menjadi dasar bagi tumbuhnya konsep berfikir abstrak bagi siswa

9. Menjadikan siswa belajar aktif dan mandiri dengan memanipulasi alat peraga, dan 
10.Bila mungkin alat peraga tersebut dapat berfaedah lipat (banyak).

Syarat dari alat perga tersebut dapat dipenuhi dengan cara membuat alat peraga yang berasal dari benda-benda yang ada disekitar lingkungan. Benda-benda yang ditemui disekitar lingkungan dapat dimanfaatkan dan disesuaikan dengan materi yang akan dijelaskan. Memanfaatkan benda-benda disekitar lingkungan memungkinkan siswa akan lebih muda memahami konsep dan meningkatkan motivasi siswa karena alat peraga yang digunakan merupakan benda-benda yang sering ditemui siswa dalam kehidupannya seharihari.

Kegiatan pengabdian kepada masyarakat yang dilakukan ini diharapkan dapat mencapai tujuan sebagai berikut: 1. Meningkatkan pengetahuan dan keterampilan guru-guru matematika SD di Kota Bengkulu tentang pembuatan alat peraga berbasis lingkungan; 2 . Meningkatkan pengetahuan dan keterampilan guru-guru matematika SD di Kota Bengkulu tentang penggunaan alat peraga berbasis lingkungan.

\section{METODE PENGABDIAN}

Sasaran strategis yang dipilih dalam pelaksanaan pengabdian ini adalah guru-guru SD pada bidang studi matematika di Kota Bengkulu. Pemilihan guru-guru tersebut sebagai sasaran pelatihan didasari pemikiran bahwa:

1. Masih kurang tersedianya alat peraga berbasis lingkungan pada pembelajaran matematika di SD-SD di Kota Bengkulu.

2. Masih kurangnya penggunaan alat peraga berbasis lingkungan pada pembelajaran matematika di SD-SD di Kota Bengkulu.

3. Sebagian besar guru SD di Kota Bengkulu belum memiliki pengetahuan dan keterampilan tentang pembuatan alat peraga matematika berbasis lingkungan.

4. Sebagian besar guru matematika SD di Kota Bengkulu belum memiliki pengetahuan dan keterampilan tentang penggunaan alat peraga berbasis lingkungan.

Alat yang digunakan pada kegiatan ini adalah benda-benda yang ada dilingkungan yang tidak terpakai lagi, misalnya kardus bekas, kertas kalender, kertas map plastik bekas, kertas map kertas, dan karung bekas. Data diperoleh dengan cara sebagai berikut:

\section{Demonstrasi}

Metode demonstrasi digunakan untuk mendemonstrasikan:

1. Cara membuat alat peraga matematika berbasis lingkungan.

2. Cara menggunakan alat peraga matematika berbasis lingkungan.

\section{Penugasan}

Metode penugasan digunakan untuk mengetahui sejauh mana pemahaman peserta pelatihan dalam menguasai materi pelatihan. Para peserta ditugaskan membuat alat peraga matematika berbasis lingkungan untuk pokok bahasan tertentu. Penugasan 
diselesaikan dengan model pendampingan oleh tim pengusul. Kegiatan ini dilaksanakan di ruang Unit PPL FKIP Universitas bengkulu.

\section{Diskusi dan tanya jawab}

Metode diskusi dan tanya jawab dilakukan sebagai bentuk interaksi antara peserta dan instruktur. Bertujuan untuk membantu peserta dalam membuat dan menggunakan alat peraga matematika berbasis lingkungan. Diskusi dan tanya jawab berlangsung selama kegiatan demonstrasi dan penugasan.

\section{HASIL DAN PEMBAHASAN}

Kegiatan ini dilaksanakan selama empat hari diruang Unit PPL FKIP Universitas Bengkulu. Peserta latihan adalah guru-guru SD kelas II dan Kela IV di Kota Bengkulu. Peserta diberi pelatihan tentang pembuatan alat peraga matematika yang terbuat dari bendabenda yang ada di lingkungan. Pada hari pertama, instruktur dan tim pengabdian memberi demonstrasi bagaimana cara membuat alat peraga matematika yang berbasis lingkungan. Ada Enam alat peraga yang kami demonstrasikan cara pembuatan dan cara menggunaknnya. Adapun alat peraga yang kami buat dapat dilihat pada Tabel 2 berikut:

Tabel 1. Jenis Alat Peraga Berbasis Lingkungan

\begin{tabular}{cll}
\hline No & \multicolumn{1}{c}{ Nama Alat Peraga } & \multicolumn{1}{c}{ Materi } \\
\hline 1. & Kartu Angka & Bilangan kelipatan dan bilangan loncat \\
2. & Kartu Positif dan Negatif & $\begin{array}{l}\text { Operasi penjumlahan dan pengurangan pada } \\
\text { bilangan bulat } \\
\end{array}$ \\
3. & Jam Analog & Waktu \\
4. & Cermin dan Kartu Pencerminan & Pencerminan \\
5. & Blok Persegi & Penjumlahan dan pengurangan angka 1 - 500 \\
6. & Corong KPK & KPK dan FPB \\
\hline
\end{tabular}

Pada hari kedua, tim pengabdian memberi demonstrasi bagaimana cara menggunakan alat peraga matematika berbasis lingkungan untuk siswa SD kelas II dan siswa kelas IV. Semua alat peraga yang dibuat dan didemonstrasikan cara penggunaannya. Pada hari ketiga, instruktur dan tim pengabdian mendemonstrasikan cara membuat alat peraga matematika yang berbasis lingkungan. Dapat dilihat pada Gambar 1 berikut: 


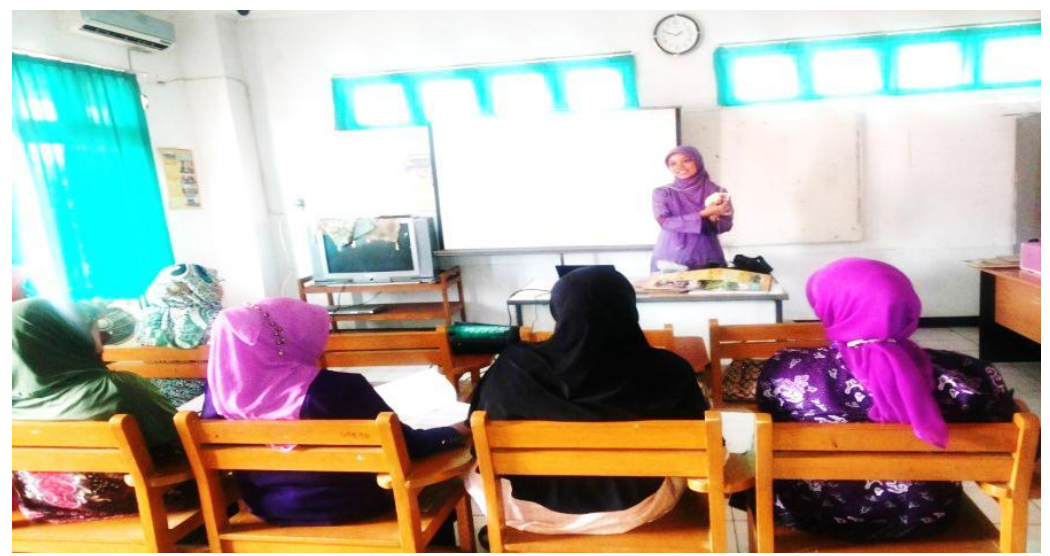

Gambar 1. Instruktur menjelaskan cara penggunaan alat peraga berbasis lingkungan

Bahan yang digunakan adalah benda-benda yang sering ditemukan disekitar lingkungan, misalnya kardus, gelas minuman mineral bekas, kertas kalender bekas, map bekas, map plastic bekas dan karung beras bekas. Peserta pelatihan dibagi dalam enam kelompok, setiap kelompok mencoba membuat satu alat peraga yang didemonstrasikan oleh tim pengabdian. Aktivitas kegiatan dapat dilihat pada Gambar 2 berikut.

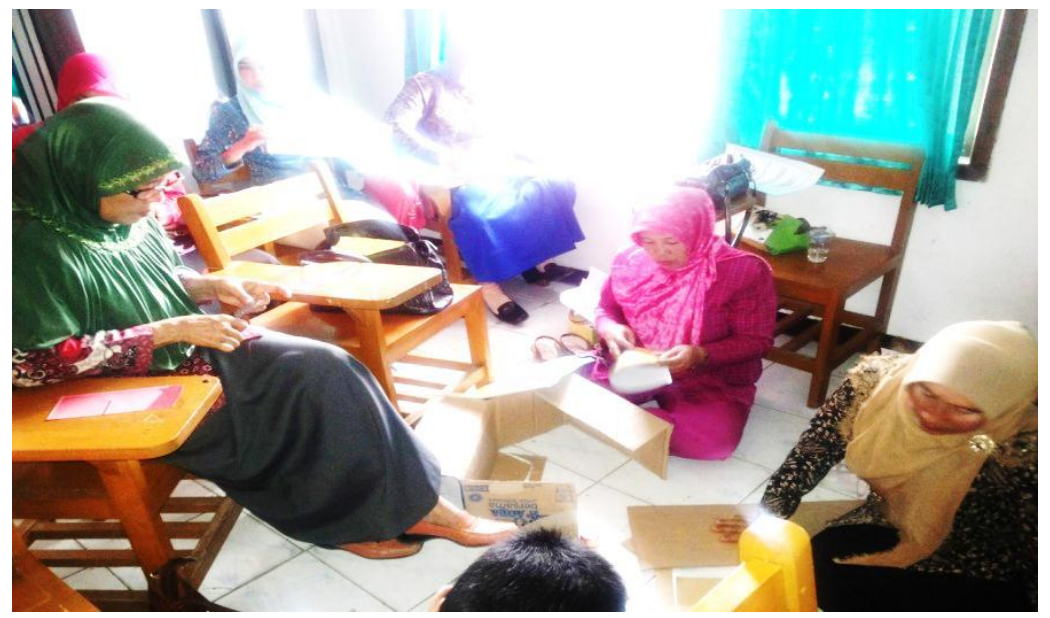

Gambar 2. Aktivitas Membuat Corong KPK

Sambil memperhatikan instruktur, peserta workshop mengikuti langkah-langkah yang dilakukan oleh instruktur. Disamping itu, jika mengalami kesulitan, peserta langsung bertanya langsung atau berdiskusi dengan instruktur.

Pada hari keempat sampai ke enam, peserta pelatihan membuat keenam alat peraga disekolah seingga setiap peserta workshop memiliki enam alat peraga matematika berbasis lingkungan. Setelah dihasilkan alat peraga matematika berbasis lingkungan guru dapat menggunakan alat peraga matematika berbasis lingkungan tersebut dalam pembelajaran 
tematik dengan kompetensi dasar yang sesuai dengan materi yang telah dijelaskan di dalam Tabel 2. Alat peraga yang dihasilkan dapat diliahat

Berdasarkan hasil observasi, diskusi, dan Tanya jawab selama kegiatan ini, diketahui bahwa pelatihan pembuatan alat peraga matematika berbasis lingkungan untuk guru-guru SD di Kota Bengkulu dapat meningkatkan pengetahuan dan keterampilan dalam membuat alat peraga matematika berbasis lingkungan. Para peserta telah dapat membuat dan menggunakan alat peraga matematika berbasis lingkungan. Kegiatan ini telah memotivasi peserta untuk memanfaatkan media pembelajaran berbasis lingkungan.

\section{KESIMPULAN DAN SARAN}

\section{Kesimpulan}

Pelatihan ini diikuti oleh lima belas guru SD sekota Bengkulu. Pelatihan ini telah meningkatkan kemampuan guru dalam menggunakan dan memanfaatkan benda yang ada disekitar lingkungan untuk dijadikan alat peraga dalam pembelajaran. Hasil penelitian ini berupa enam buah alat peraga berbasis lingkungan yang dapat digunakan oleh guru SD dalm menjelaskan materi bilangan loncar, penjumlahan dan pengurangan angka 1 - 500, waktu, pencerminan, operasi pada bilangan bulat, KPK dan FPB.

\section{Saran}

Berdasarkan pelaksanaan pelatihan yang telah dilakukan maka saran yang dapat diberikan antara lain:

1. Sekolah dapat memanfaatkan benda-benda yang ada disekitar lingkungan untuk pembuatan alat peraga, sehingga akan banyak terdapat alat peraga disekolah yang dapat digunakan oleh guru dalam pembelajaran.

2. Siswa dapat memanfaatkan media pembelajaran berupa alat peraga dengan langsung melihat bentuk konkrit dari materi yang dipelajari, ini dapat terlaksana jika media pembelajaran yang berupa alat peraga tersedia banyak disekolah.

\section{DAFTAR PUSTAKA}

Asyar, Rayandra, 2012, Kreatif Mengembangkan Media Pembelajaran, Referensi, Jakarta, Jambi.

Sundayana, Rostina, 2013, Media Pembelajaran Matematika, Alfabeta, Bandung. 
